\title{
MIGRASI DAN JARINGAN EKONOMI SUKU BUGIS DI WILAYAH TANAH BUMBU, KERESIDENAN BORNEO BAGIAN SELATAN DAN TIMUR, 1930-1942
}

\author{
Mansyur \\ Jurusan Pendidikan Sejarah Fakultas Keguruan dan Ilmu Pendidikan \\ Universitas Lambung Mangkurat
}

Alamat Korespondensi: mansyur_daeng@yahoo.com

Diterima/ Received: 20 Desember 2015; Disetujui/ Accepted: 28 Januari 2016

\begin{abstract}
The Bugis migration to Tanah Bumbu, Afdeeling Pasir en de Tanah Boemboe, Residentie Borneo's Zuid en Oosterafdeeling continued until the early decades of the 20th century, especially in 1930-1942. It was indirectly indicates how strong economic motives of the Bugis. In an effort to survive in the midst of economic depression or malaise, Bugis migrants "creates" economic adaptation strategy to establish a network of fisheries Ponggawa (skipper) Bugis in the early 1930's. Most migrant Bugis also tried farmer (bahuma) for copra and coconut planting. Plantation crops are suitable and almost the same as plantation crops in South Sulawesi. In addition, in the field of marine migrant boat Bugis also developed business people to serve the marine transportation. This study uses the history of the historical method, which is a method to test and analyze critically the recording and relics of the past. The historical method comprises step heuristics, criticism of sources (external and internal), interpretation and historiography.
\end{abstract}

Keywords: migration, economy networks, Bugis.

\begin{abstract}
Abstrak
Kontinuitas migrasi Suku Bugis ke landschap Tanah Bumbu, Afdeeling Pasir en de Tanah Boemboe, Residentie Borneo's Zuid en Oosterafdeeling terus berlangsung hingga dekade awal abad ke-20, khususnya 1930-1942. Migrasi yang berlangsung pada masa akhir kekuasaan Hindia Belanda ini secara tidak langsung mengindikasikan begitu kuatnya keinginan bertahan hidup dan motif ekonomi Suku Bugis. Dalam upaya bertahan di tengah depresi ekonomi atau malaise, migran Bugis "menciptakan" strategi adaptasi ekonomi dengan membentuk jaringan perikanan ponggawa (juragan) Bugis pada awal 1930-an. Sebagian migran Bugis juga berusaha tani (bahuma) dan menanam kelapa untuk kopra. Tanaman perkebunan ini cocok dan hampir sama dengan tanaman perkebunan di Sulawesi Selatan. Selain itu, dalam bidang kelautan migran Bugis juga mengembangkan usaha perahu rakyat untuk melayani transportasi laut. Penelitian ini menggunakan metode sejarah, yakni metode untuk menguji dan menganalisa secara kritis rekaman dan peninggalan masa lampau. Metode sejarah terdiri dari tahap heuristik, kritik sumber (ekstern dan intern), interpretasi dan historiografi.
\end{abstract}

Kata Kunci: migrasi, jaringan ekonomi, Bugis.

\section{PENDAHULUAN}

Orang Bugis mulai bermigrasi ke berbagai wilayah di Nusantara secara intensif sejak awal abad ke-17. Migrasi tersebut secara umum didorong oleh faktor ekonomi dan non- ekonomi, seperti tidak adanya ketentraman jiwa, peperangan, kehilangan kemerdekaan, dan juga filosofi yang dipegang, khususnya orang Bugis dari Wajo yang berprinsip Maradeka to-Wajo'e ade'mi napopuwang (rakyat Wajo itu merdeka dan hanya hukumlah yang menjadi tuan). Dalam 
arti lain, jika dalam penyelenggaraan pemerintahan hukum tidak bisa ditegakkan, maka orang Bugis dan Makassar akan bermigrasi meninggalkan daerahnya menuju daerah lain. Hal ini bisa dimaknai sebagai bentuk protes terhadap kezaliman rezim berkuasa.

Gelombang migrasi besar-besaran Suku Bugis ke berbagai wilayah di Nusantara terjadi hampir bersamaan dengan ekspansi pemerintahan kolonial Belanda secara total atas seluruh wilayah Sulawesi Selatan (Zuid Celebes) pada 1906. Belanda memperluas wilayah kekuasaannya sampai ke pedalaman, menaklukkan wilayah Bone pada 1905 hingga Tana Toraja pada 1907. Selain penaklukan, tekanan-tekanan juga dilakukan pemerintah kolonial Belanda, antara lain dalam bentuk kerja paksa dalam pembuatan jalan dan kegiatan lainnya untuk kepentingan pemerintah Belanda. Banyak petani yang tidak dapat mengerjakan sawah dan ladangnya karena harus mencurahkan perhatiannya pada kegiatankegiatan pembangunan yang berkaitan dengan kepentingan penjajah. Penetrasi kapitalis Belanda menjalar sampai ke daerah perdesaan Sulawesi Selatan. Bukan hanya tekanan fisik dan psikis yang dialami penduduk, tetapi perbedaan kelas sosial semakin nyata dan feodalisme meningkat.

Kondisi tersebut turut meningkatkan arus gerak penduduk ke luar Sulawesi Selatan. Ketergantungan, kelompok pengikut atau rakyat jelata yang berada pada status sosial ekonomi rendah kepada kelompok atas, elit tradisional, dan pemilik alat-alat produksi semakin tampak. Apalagi kelompok elit tradisional memperoleh berbagai kemudahan dan kesempatan dari pemerintah kolonial Belanda untuk memperkuat kekuasaannya atas kelompok ekonomi rendah. Ketimpangan sosial ekonomi antara kelompok melebar, sehingga terjadi gerak penduduk ke luar daerah, dalam istilah Bugis disebut mallekke' dapureng atau pindah menetap.

Menurut Mattulada, mallekke' dapureng (pindah menetap) adalah pilihan paling aman untuk berpindah ke luar daerah. Hal ini memicu migrasi orang Bugis secara besar-besaran ke seluruh Nusantara. Alasan utama adalah karena merasa siri' (malu) dengan keadaan tersebut, mereka kemudian memutuskan hijrah ke tempat lain. Satu di antara lokasi yang menjadi tujuan migrasi Suku Bugis di Borneo (Kalimantan) adalah landschap Tanah Bumbu, Afdeeling Pasir en de Tanah Boemboe, Residentie Borneo's Zuid en Oosterafdeeling (Karesidenan Borneo Bagian Selatan dan Timur). Alasannya, lokasi Borneo (Kalimantan) strategis dan berdekatan dengan Sulawesi Selatan, kemudian memiliki banyak lahan yang bisa digarap menjadi area pertanian dan perkebunan kelapa, serta potensi perikanan melimpah. Wilayah landschap Tanah Bumbu terdiri dari distrik Batulicin, Cantung, Bangkalaan, Sampanahan, Manunggal, Cengal, Pagatan, Kusan, Buntar Laut, Pulau Laut dan Sebamban (Hollander, 1864: 143).

Oleh karena itu tulisan ini ingin memberikan gambaran yang jelas tentang latar belakang migrasi penduduk suku Bugis ke landschap Tanah Bumbu, Afdeeling Pasir en de Tanah Boemboe, Keresidenan Borneo Bagian Selatan dan Timur, pada masa kolonial. Selain itu, tulisan ini ingin menjelaskan jaringan ekonomi yang terbentuk sebagai dampak atas aktivitas migrasi suku Bugis ke Borneo (Kalimantan).

\section{METODE}

Metode yang digunakan dalam penelitian ini adalah metode sejarah yang meliputi tahap heuristik, verifikasi (kritik sejarah, keabsahan sumber), interpretasi dan historiografi. Heuristik adalah kegiatan mencari dan menemukan sumber-sumber sejarah, baik primer maupun sekunder. Adapun tempat pencarian sumbersumber bagi penelitian ini antara lain Perpustakaan Nasional Republik Indonesia, Lembaga Ilmu Pengetahuan Indonesia (LIPI), dan Arsip Nasional Republik Indonesia (ANRI). Sumber lain berupa artikel yang diperoleh melalui penelusuran situs-situs internet dengan mengunjungi website yang berhubungan dengan sejarah. Selain itu digunakan pula sumber kepustakaan yang relevan, baik yang diterbitkan maupun yang tidak diterbitkan seperti disertasi, tesis, dan laporan penelitian lainnya. 
Tahap verifikasi atau pengujian atas kebenar-an data kemudian dilakukan dengan cara kritik sumber-sumber yang telah diperoleh. Kritik sumber atau teks merupakan kegiatan yang bertujuan menyelidiki dan menguji apakah sumber-sumber sejarah yang ditemukan bisa dipercaya (kredibel) baik bentuk maupun isinya. Tahap ini merupakan kegiatan mencari fakta sejarah. Selanjutnya dilakukan interpretasi, yaitu kegiatan menetapkan makna dan saling menghubungkan fakta-fakta sejarah yang diperoleh. Tahap yang terakhir yaitu historiografi atau rekonstruksi sejarah, yaitu menyajikan hasil penelitian dalam bentuk tulisan sejarah.

\section{LETAK GEOGRAFIS DAN ADMINISTRATIF TANAH BUMBU}

Landschap Tanah Bumbu pada awalnya merupakan daerah onderafdeeling yang dikenal dengan nama onderafdeeling van Tanah Boemboe pada 1844. Adapun distrik-distrik yang tergabung dalam wilayah ini yaitu Pagatan, Kusan, Batulicin, Cantung, Bangkalan, Sampanahan, Manunggal, Buntar Laut, dan Cengal. Menurut Staatsblad 1849 No. 8, wilayah Tanah Bumbu dan daerah Kotawaringin, Sampit, Pembuang, Mendawai, Tanah Laut, Dusun Ilir, Pasir, Kutai, Berau termasuk dalam Borneo Zuid Ooster Afdeeling (Afdeeling Borneo Selatan dan Timur) yang beribukota di Banjarmasin. ${ }^{1}$ Sementara wilayah Pulau Laut dan Batulicin berada di bawah pemerintah Kusan (Schwaner, 1853: 357; Bleckmann, 1953: 354).

Dalam perkembangan sejak 1898 , terjadi perubahan pembagian wilayah lokal administratif, seperti yang terdapat dalam Staatblad 1898 No. 178. Wilayah Tanah Bumbu menjadi satu afdeeling yang bernama Afdeeling Pasir en de Tanah Boemboe dalam wilayah Residentie Borneo's Zuid en Ooster-afdeeling (Keresidenan Borneo bagian Selatan dan Timur) (Ideham, et. al., 2003: 233). Wilayah ini membawahi wilayah sebelumnya ditambah Pulau Laut dan Sebamban menjadi distrik tersendiri (Bleckmann, 1953: 351).
Perubahan administratif kemudian terjadi pada 1936, walaupun pada dasarnya masih menerapkan sistem pemerintahan sipil kolonial. Afdeeling Tanah Bumbu berubah status menjadi onderafdeeling yakni Onderafdeeling Tanah Bumbu dan Pulau Laut, di bawah Afdeeling Banjarmasin. Selain itu, terdapat Onderafdeeling Banjarmasin, Marabahan, Martapura dan Pleihari. Onderafdeeling Tanah Bumbu dan Pulau Laut membawahi beberapa distrik yakni Pagatan, Kusan, Cengal, Manunggal, Bangkalaan, Sampanahan, Cantung, Batulicin, Sebamban, Pulau Laut dan Pulau Sebuku (Korch, 2009).

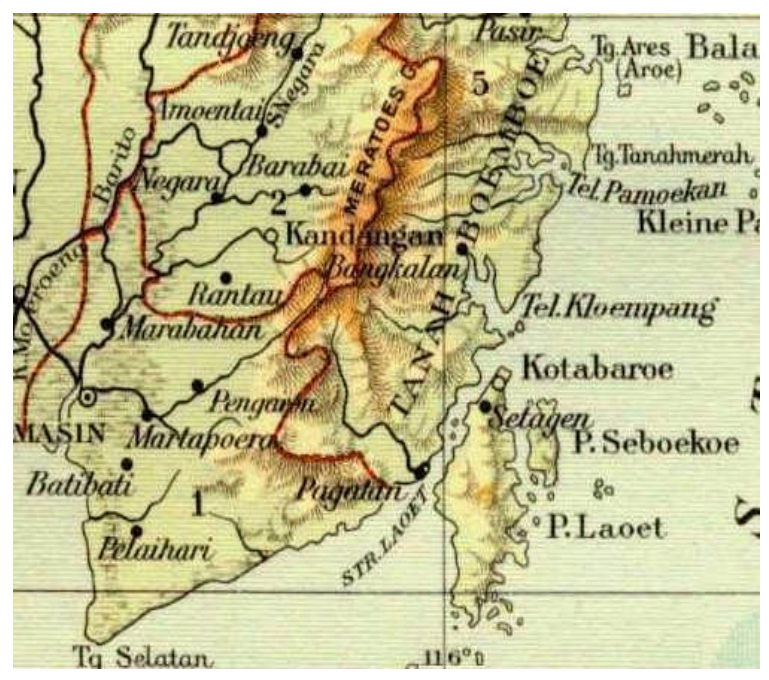

Gambar 1. Peta wilayah Afdeeling Pasir en de Tanah Boemboe, Keresidenan Borneo Bagian Selatan dan Timur.

Sumber: Stanford's Geographical Establishment, 1919.

Dari catatan J.J. Hollander pada 1864, wilayah Tanah Bumbu memiliki luas sekitar 141,5 mil persegi dengan beberapa daerah (distrik) yakni Batulicin, Cantung, Bangkalaan, Sampanahan, Manunggal dan Cengal (Hollander, 1864). Dari catatan tersebut belum memasukkan tambahan wilayah Pulau Laut, Pagatan dan Tanah Kusan dalam wilayah Tanah Bumbu karena kedua wilayah baru bergabung dalam Afdeeling Pasir en de Tanah Boemboe pada 1898. Tanah Bumbu berbatasan dengan daerah Pasir di sebelah utara, di sebelah timur dengan Selat Makassar, berbatasan dengan Tanah Kusan di sebelah selatan, dan sebelah barat berbatasan dengan daerah Banjarmasin (Veth, 1869: 637). 


\section{INTENSITAS PERSEBARAN SUKU BUGIS}

Linneton beranggapan bahwa migrasi suku Bugis ke berbagai wilayah di Nusantara, lebih disebabkan oleh daya tarik tersendiri. Hal utama yang paling signifikan yang memengaruhi migrasi Bugis ke daerah-daerah lain dalam empat dekade pertama abad kedua puluh adalah boom tanaman pertanian dan perkebunan primer khususnya padi, karet, dan kopra. Sebagian besar imigran Bugis ke Borneo (Kalimantan) dan Malaya terlibat dalam penanaman karet dan kelapa untuk kopra serta tidak lagi menanam tanaman-tanaman untuk produksi pertanian subsistensi seperti di wilayah Sulawesi Selatan. Hingga tahun 1930, lebih dari sepuluh persen dari etnis Bugis berdomisili di luar Sulawesi Selatan (Linneton, 1973: 181).

Mattulada menyebutkan migrasi orang Bugis disebabkan oleh keadaan yang tidak aman secara terus-menerus di Sulawesi Selatan karena adanya berbagai peperangan sejak abad ke-18. Alasan ekonomi juga turut mendorong migrasi Bugis, seperti masalah keterbatasan lahan pertanian di beberapa daerah di Sulawesi Selatan seperti Bone dan Wajo (Naim, 1979: 42; Hugo, 1987: 31-37). Berbeda dari kondisi di wilayah Pinrang, Maros, Pangkajene, Sidrap, penduduk pada umumnya mempunyai cukup sawah untuk bercocok tanam, sehingga jarang yang melakukan migrasi ke luar Sulawesi Selatan. Sebuah pengecualian mungkin terdapat pada masyarakat Sengkang, Sulawesi Selatan. Mereka membawa kopra dan hasil-hasil produksi daerah mereka ke Pulau Jawa dan kembali membawa barang berupa semen, gula, barang barang besi, tekstil, dan sebagainya (Naim, 1979: 42).

Migrasi utama yang tercatat dalam sensus ini adalah migrasi dari Sulawesi Selatan ke Borneo (Kalimantan) bagian Selatan, migrasi dari Jawa ke Sumatera, terutama Sumatera Timur dan Lampung, dan migrasi dari Borneo (Kalimantan) Selatan ke Sumatera, terutama ke Riau dan Jambi. Selain itu, terdapat juga sejumlah migrasi besar dari berbagai daerah di Indonesia ke Semenanjung Malaya, terutama dari Jawa, Borneo (Kalimantan) Selatan,
Sumatera, Sulawesi Selatan, dan Pulau Kecil Bawean. $^{2}$

Menurut Mochtar Naim, intensitas migrasi Bugis ke luar wilayah sendiri pada 1930 menduduki peringkat kelima setelah suku Bawean, Batak, Banjar dan Minangkabau. Selain kelima suku tersebut terdapat suku lain yang intensitas migrasinya tinggi, yakni Manado, Ambon, Bengkulu dan Mandar. Suku-suku bangsa yang intensitas migrasinya lebih rendah adalah Jawa, Sunda, Madura, Bali, Sasak, Timor, Makassar, Toraja, Dayak, Melayu Pesisir, Aceh, Jambi, Palembang, Lampung dan Nias. Jumlah suku Bugis yang bermigrasi ke luar wilayahnya 162.701 orang (10,5\%) (Naim, 1979: 44).

Berdasar Volkstelling 1930, jumlah orang Bugis di Nusantara berjumlah sekitar 1.533.035 orang. Pada wilayah Sulawesi Selatan sendiri jumlah orang Bugis adalah 1.380.334 orang. Jumlah orang Bugis yang merantau ke Borneo (Kalimantan) menduduki tempat teratas dalam migrasi orang Bugis ke wilayah Nusantara dan semenanjung Malaya. Dari sensus 1930, diketahui jumlah orang Bugis yang bermigrasi ke Borneo (Kalimantan) adalah 95.048 jiwa atau sekitar 60,29\% dari jumlah migrasi orang Bugis ke pulau lainnya seperti Sumatera, Jawa, Bali dan Nusa Tenggara, Maluku dan Irian Jaya, Sulawesi Utara dan Tengah dan Malaysia. Setelah Borneo (Kalimantan), yang menempati peringkat kedua adalah migrasi Bugis ke Sulawesi Utara dan Tengah yang berjumlah 27.477 jiwa atau 17,43\% dari total migrasi Bugis ke Nusantara. Kemudian migrasi Bugis ke wilayah Bali dan Nusa Tenggara berjumlah sekitar 14.120 jiwa atau 8,96\%. Sementara itu migrasi ke Sumatera adalah 10.170 jiwa atau sekitar 6,45\%, hampir sebanding dengan migrasi ke Malaysia yang berjumlah 10.000 jiwa atau 6,30\%. Berikutnya migrasi ke Jawa berjumlah 4.593 jiwa atau 2,91\%, sedangkan migrasi terkecil adalah migrasi Bugis ke Maluku dan Irian Jaya jumlahnya adalah sekitar 1.293 jiwa atau 0,82\%. Jumlah ini cukup besar dibandingkan dengan jumlah orang Makassar, Mandar dan Toraja yang juga bermigrasi ke daerah lainnya (Naim, 1979: 42). Dari jumlah migran tersebut dapat dirinci per 
jenis kelamin, yang ditampilkan dalam Tabel 1 berikut.

Tabel 1. Emigrasi Bugis menurut Daerah Asal dan Jenis Kelamin, 1930

\begin{tabular}{llll}
\hline Daerah Asal & Laki Laki & Perempuan & Total \\
\hline Pare Pare & 5.479 & 3.858 & 9.328 \\
Makassar & 9.812 & 6.063 & 16.175 \\
Enrekang & 5.436 & 5.640 & 11.076 \\
Sinjai & 6.448 & 6.188 & 12.636 \\
Gowa & 6.970 & 5.533 & 12.503 \\
Majene & 4.720 & 3.449 & 8.169 \\
Soppeng & 6.896 & 6.512 & 13.408 \\
Maros & 6.007 & 5.309 & 11.316 \\
Bone & 21.000 & 16.788 & 37.848 \\
Bantaeng & 3.821 & 3.279 & 7.100 \\
Sidenreng & 6.442 & 5.501 & 11.943 \\
Rappang & & & \\
Wajo & 10.247 & 7.001 & 17.248 \\
\hline
\end{tabular}

Sumber: Departement van Landbouw, Nijverheid en Handel, 1930.

Tabel 1. menunjukkan bahwa migrasi orang Bugis ke luar Sulawesi Selatan berasal dari 12 daerah di atas. Bone dan Wajo merupakan daerah pengirim migran Bugis ke luar Sulawesi Selatan yang terbesar, walaupun hanya $11 \%$ dan 9\% dari jumlah penduduknya masing-masing. Migran Makassar, yang jumlahnya lebih sedikit, terutama berasal dari Makassar dan Gowa, tetapi dengan persentase migrasi keluar dari jumlah penduduknya lebih besar, masing-masing $16 \%$ dan $12,4 \%$.

Terkait komposisi suku bangsa di wilayah Keresidenan Borneo Bagian Selatan dan Timur (tidak termasuk wilayah Pasir dan Distrik Satui), Gooszen menyebutkan bahwa pada 1930, terdapat suku Dayak sebanyak 33.821 orang (8,63\%). Selanjutnya suku Banjar sebanyak 254.399 orang $(64,91 \%)$, suku Jawa sebesar 36.451 orang $(9,30 \%)$ dan suku Bugis sebanyak 43.340 orang $(11,06 \%)$. Sementara itu, suku lainnya (Mandar, Bajau dan lain-lain) sebesar 23.916 orang (6,10\%). Data tersebut menempatkan penduduk dari suku Bugis pada posisi kedua terbanyak di wilayah Keresidenan Borneo Bagian Selatan dan Timur. Menurut Gooszen, hal ini menunjukkan adanya intensitas migrasi Bugis yang tinggi dari wilayah Sulawesi Selatan (Gooszen, 1999: 108-111).

Data sensus penduduk (Volkstelling) 1930 memberikan gambaran yang berbeda. Di daerahdaerah seperti Tanah Bumbu dan Pulau Laut di wilayah Keresidenan Borneo Bagian Selatan dan Timur, jumlah suku Bugis di kedua tempat tersebut secara berurutan berjumlah sekitar $29,66 \%$ dan $15,70 \%$ dari total seluruh penduduk yang ada di masing-masing daerah. Data selengkapnya disajikan pada Tabel 2.

Tabel 2. Jumlah Penduduk Suku Bugis di Wilayah Borneo (Kalimantan) Menurut Sensus Penduduk 1930

\begin{tabular}{|c|c|c|c|c|}
\hline No & Daerah & $\begin{array}{l}\text { Laki } \\
\text { Laki }\end{array}$ & Perempuan & Total \\
\hline 1. & Sambas & 178 & 196 & $\begin{array}{c}374 \\
(0,58)\end{array}$ \\
\hline 2. & Mempawah & 965 & 877 & $\begin{array}{l}1.824 \\
(4,18)\end{array}$ \\
\hline 3. & Pontianak & 19.601 & 18.398 & $\begin{array}{l}37.999 \\
(53,48)\end{array}$ \\
\hline 4. & Landak & 189 & 162 & $\begin{array}{c}351 \\
(0,56)\end{array}$ \\
\hline 5. & Soekadana & 330 & 290 & $\begin{array}{c}620 \\
(2,91)\end{array}$ \\
\hline 6. & Boneden-Matan & 222 & 187 & $\begin{array}{c}409 \\
(2,40)\end{array}$ \\
\hline 7. & Poeloelaoet & 2.046 & 1.891 & $\begin{array}{c}3.937 \\
(15,70)\end{array}$ \\
\hline 8. & Tanahboemboe & 5.852 & 6.143 & $\begin{array}{l}11.995 \\
(29,66)\end{array}$ \\
\hline 9. & Pasir & 4.510 & 4.407 & $\begin{array}{c}8.917 \\
(22,35)\end{array}$ \\
\hline 10. & Balikpapan & 4.768 & 3.335 & $\begin{array}{c}8.103 \\
(51,81)\end{array}$ \\
\hline 11. & Oost Koetai & 4.152 & 3.493 & $\begin{array}{c}7.645 \\
(21,62)\end{array}$ \\
\hline 12. & West Koetai & 1.582 & 984 & $\begin{array}{l}2.566 \\
(3,15)\end{array}$ \\
\hline 13. & $\begin{array}{l}\text { Boven } \\
\text { Mahakam }\end{array}$ & 191 & 174 & $\begin{array}{c}365 \\
(3,03)\end{array}$ \\
\hline 14. & Beraoe & 1.003 & 626 & $\begin{array}{l}1.629 \\
(8,33)\end{array}$ \\
\hline 15. & Boeloengan & 344 & 237 & $\begin{array}{c}581 \\
(3,43)\end{array}$ \\
\hline 16. & Pontianak* & 1.924 & 1.730 & $\begin{array}{c}3.654 \\
(13,45)\end{array}$ \\
\hline 17. & Kotabaroe * & 120 & 100 & $\begin{array}{c}220 \\
(7,72)\end{array}$ \\
\hline 18. & Balikpapan* & 1.230 & 721 & $\begin{array}{l}1.951 \\
(8,33)\end{array}$ \\
\hline 19. & Samarinda* & 360 & 212 & $\begin{array}{c}572 \\
(6,80)\end{array}$ \\
\hline
\end{tabular}




\begin{tabular}{|c|c|c|c|c|}
\hline 20. & Tandjongseilor* & 140 & 147 & $\begin{array}{c}287 \\
(23,66)\end{array}$ \\
\hline 21. & Tarakan * & 171 & 66 & $\begin{array}{c}237 \\
(2,87)\end{array}$ \\
\hline
\end{tabular}

Sumber: Departement van Landbouw, Nijverheid en Handel,1930: 28.

\section{Keterangan :}

1. Wilayah urutan 1- 15 adalah wilayah onderafdeling dan daerah di luar kota.

2. Wilayah urutan 16-20 (bertanda *) adalah wilayah gemeente dan kota.

Tabel tersebut menunjukkan penduduk Bugis di wilayah Pulau Laut dan Tanah Bumbu pada 1930 mencapai 15.932 orang. Total penduduk Bugis 3.937 orang atau 15,70\% dari seluruh penduduk Pulau Laut, terdiri atas 2.046 orang laki-laki dan 1.891 orang perempuan. Sementara itu, penduduk Bugis di Tanah Bumbu secara keseluruhan 11.995 orang atau sekitar 44,1\% dari seluruh penduduk Onderafdeeling Tanah Bumbu dan Pulau Laut. Jumlah ini terdiri atas laki-laki 5.852 orang dan perempuan 6.143 orang. Penduduk Bugis di Tanah Bumbu dan Pulau Laut umumnya bertempat tinggal di pedesaan dan pesisir pantai. Seperti terdapat dalam data, di Gemeente Kotabaru (ibukota Onderafdeeling Tanah Bumbu dan Pulau Laut), hanya 220 orang Bugis yang bertempat tinggal di perkotaan, sisanya di kampung dan pesisir pantai.

\section{EKSISTENSI PONGGAWA BUGIS PADA DEPRESI EKONOMI 1930-AN}

\section{Kalangan “To Maradeka” Membangun Usaha Perikanan}

Satu di antara dampak migrasi Bugis ke wilayah Tanah Bumbu adalah munculnya jaringan ekonomi orang Bugis di wilayah Keresidenan Borneo (Kalimantan) Bagian Selatan dan Timur. Untuk melihat jaringan ekonomi orang Bugis pada 1930-an tidak terlepas dari perkembangan kondisi perekonomian di Hindia Belanda pada umumnya. Pada 1930-an, dilaporkan banyak masyarakat Hindia Belanda yang harus kehilangan pekerjaannya, terutama para pekerja perkebunan akibat terjadinya depresi ekonomi, karena perdagangan internasional mengalami kemunduran (Burger, 1960: 190). Bagi rakyat zaman ini sering disebut dengan zaman meleset (dari kata malaise), yang berarti pengurangan kesempatan kerja, pemotongan gaji, penurunan harga-harga hasil pertanian, rendahnya upah, dan kenaikan pajak. Semua itu merupakan akibat dari politik (kebijakan) ekonomi yang di satu pihak bermaksud menjalankan penghematan secara besar-besaran dan di pihak lain hendak mempertahankan pendapatan ekspor terutama yang diperoleh dari hasil perkebunan (Kartodirdjo, 1999). Hal ini juga berpengaruh secara umum terhadap migrasi di Hindia Belanda umumnya dan di wilayah Borneo khususnya. Para migran mengembangkan kegiatan ekonomi untuk meningkatkan taraf hidupnya di tanah rantau.

Diperkirakan hampir semua migran Bugis yang datang secara bergelombang ke kawasan Tanah Bumbu pada 1900 hingga 1930-an, umumnya berasal dari kalangan petani dan nelayan. Mereka berasal dari lapisan sosial to maradeka (orang merdeka atau penduduk biasa), yang melakukan mallekke dapureng (migrasi menetap) karena ingin melepaskan diri dari kesulitan di bidang ekonomi dan meningkatkan taraf kehidupannya di daerah rantau. Kemudian mereka ingin menyelamatkan diri dari kekacauan militer karena pendudukan Belanda di Sulawesi Selatan (Lenggono, 2011: 120).

Seperti dikemukakan Lenggono, fenomena di wilayah Borneo (Kalimantan) terutama Kalimantan bagian timur, banyak di antara ponggawa-ponggawa (juragan-juragan) sukses di wilayah ini yang berasal dari lapisan to maradeka. Mereka berasal dari keluarga sederhana yang jauh dari berkecukupan, tepatnya dari strata bawah dalam sebuah masyarakat di suatu kampong (Lenggono, 2011). Demikian pula yang terjadi di wilayah Tanah Bumbu, struktur sosial masyarakat migran Bugis di kawasan Tanah Bumbu sepertinya tidak hanya membuka peluang bagi golongan elit tradisional Bugis (anakarung), 
tetapi juga memberikan kesempatan yang luas bagi golongan to-maradeka (orang merdeka atau penduduk biasa) memasuki bidang kegiatan ekonomi perikanan seperti penangkapan ikan yang mulai berkembang pada 1930-an (Wawancara dengan Andi Tajuddin, 2012).

Menurut Lenggono, status tanah negara di daerah tujuan, khususnya pulau-pulau di kawasan pesisir Borneo (Kalimantan) bagian selatan dan timur yang luas namun tidak memiliki nilai intrinsik dan absennya Pemerintah Hindia Belanda di dalam pengaturan kawasan coastal frontiers (bagian pesisir) ini menjadi salah satu alasan penting mengapa migran Bugis dari golongan to-maradeka (orang merdeka atau penduduk biasa) dalam strata masyarakat Bugis feodal lebih berpeluang memasuki kegiatan perikanan (Lenggono, 2011). Kegiatan perikanan memerlukan bidang tanah yang sangat luas untuk dibangun dan dikembangkan menjadi area pertambakan dan membuat usaha penangkapan ikan yang dapat memasok jumlah ikan dalam jumlah besar (Lenggono, 2011: 120).

Pada masa awal kedatangannya, anggota elit tradisional migran Bugis tampaknya kurang tertarik terhadap beberapa wilayah pesisir kawasan Tanah Bumbu yang berawa rawa dan relatif sulit diolah dan diubah menjadi kawasan pertanian atau perkebunan yang potensial selain tidak memiliki sumber mata air yang memadai. Oleh karena itu, para migran dari kalangan elit tradisional yang biasanya membawa serta para pengikutnya tersebut, lebih cenderung membuka daerah-daerah baru (di sekitar hutan yang masih merupakan kesatuan dengan Pulau Borneo (Kalimantan), yang tanahnya lebih subur dan sangat potensial untuk dikembangkan menjadi kawasan pertanian (sawah atau palawija) atau perkebunan (lada, kelapa dan buah-buahan), serta memiliki sumber mata air melimpah. Pertimbangan tersebut juga didasarkan kepentingan pragmatis untuk dapat segera mendapatkan hasil produksi memadai, sehingga dapat mempertahankan stabilitas ekonomi untuk menghidupi keluarga besar mereka, berikut keberlangsungan klientisme yang masih mereka pertahankan (Lenggono, 2011: 120).
Sementara itu, masyarakat asli setempat yakni Dayak dan Banjar, serta keturunan dari migran Banjar, Jawa dan Bugis yang dilahirkan di sekitar kawasan Tanah Bumbu, relatif tidak tertarik untuk menggarap tanah-tanah di sekitar pulau pulau dan pesisir Kawasan Tanah Bumbu. Alasannya karena tidak memiliki pengetahuan memadai dalam mengembangkan dan mengubah tanah rawa-payau tersebut menjadi usaha ekonomi alternatif. Hanya sebagian kecil dari keturunan migran Bugis ini yang kemudian berhasil membuka kawasan hutan mangrove tersebut menjadi area perkebunan kelapa berskala kecil. Sementara sebagian besar dari mereka lebih suka memilih tetap melanjutkan pekerjaan orang tuanya sebagai nelayan tradisional atau bertani tadah hujan dibandingkan harus membuka hutan mangrove yang membutuhkan pengorbanan tenaga, waktu dan materi yang tidak kecil (Lenggono, 2011: 120). Dalam Laporan Augustu de Wit, disebutkan bahwa vegetasi mangrove banyak ditemukan di wilayah Borneo (Kalimantan) bagian selatan, di muara sungai dan wilayah Tanjung Selatan. Vegetasi mangrove juga banyak terdapat di pantai-pantai wilayah Tanah Bumbu dan sepanjang daerah aliran sungai di Tanah Laut hingga beberapa kilometer persegi (de Wit, 1926: 339).

Beberapa di antara orang Bugis di Borneo (Kalimantan) bagian selatan dan timur yang memiliki kemampuan finansial memadai, mencoba menjadi pengumpul hasil perikanan tangkap untuk kemudian dijual secara berkala ke daerah lain dalam bentuk ikan asin atau udang olahan. Mereka inilah yang digolongkan sebagai ponggawa (juragan) perintis, beberapa orang di antaranya adalah migran dari golongan elit tradisional Bugis (anakarung) yang memiliki beberapa unit armada kapal atau perahu tangkap sendiri. Sementara itu, lainnya berasal dari golongan to-maradeka (orang merdeka atau penduduk biasa). Sangat menarik bahwa ponggawa (juragan) perintis yang berasal dari golongan elit tradisional (anakarung) cenderung berdomisili di daerah yang masih satu-kesatuan dengan mainland Pulau Borneo (Kalimantan), 
sementara domisili ponggawa perintis dari golongan to-maradeka (orang merdeka atau penduduk biasa) cenderung tersebar ke pulaupulau di kawasan Tanah Bumbu.

Dalam kondisi seperti inilah migran Bugis dari golongan to-maradeka yang datang secara berkelompok sejak awal 1900-an mulai berbondong-bondong datang ke kawasan Tanah Bumbu. Dengan meminta izin tinggal-garap pada para toa/kampoeng atau kepala kampung, secara berkelompok mereka kemudian mulai menempati tempat-tempat strategis di sekitar wilayah toa/kampoeng Pejala dan Pakkaja yang jumlahnya ratusan buah di dalam kawasan Tanah Bumbu atau menetap di sekitar perkampungan. Meskipun tidak sedikit di antara mereka yang langsung menetap di suatu tempat tanpa meminta izin dan baru melaporkan keberadaannya pada aparat kampung yang berwenang jika menghadapi konflik atau masalah. Tidak berbeda dengan migran yang telah menetap sebelumnya, mereka juga memulai aktivitas ekonominya dari kegiatan perikanan tangkap dan nelayan tradisional (Nuralang, 2007: 11).

Beratnya kehidupan di daerah coastal frontiers yang jauh dari layak dan nyaman untuk dihuni membuat mereka harus beradaptasi di daerah-daerah baru yang belum terjamah dan dikuasai orang lain dan relatif terisolir. Hal ini tampaknya bisa menjadi penjelas mengapa para migran dari golongan to-maradeka (orang merdeka atau penduduk biasa) tersebut membawa nilai we're' (untuk tidak tunduk pada nasib), sehingga mereka bisa bertahan dalam himpitan hidup dengan keterbatasan (Lenggono, 2011: 120). Penggolongan penduduk dan akses terhadap tanah di wilayah Tanah Bumbu 1930-an dalam Tabel 3.

Tabel 3. Penggolongan Penduduk dan Akses Terhadap Tanah di Wilayah Tanah Bumbu 1930-1942

\begin{tabular}{llll}
\hline Penggolongan Penduduk & $\begin{array}{c}\text { Akses } \\
\text { Terhadap } \\
\text { Tanah }\end{array}$ & $\begin{array}{l}\text { Orientasi } \\
\text { Ekonomi }\end{array}$ \\
\hline Warga & Warga Asli (Dayak, & Penguasa- & Untuk \\
Setem & Banjar dan Bugis & an Tanah & keperluan
\end{tabular}

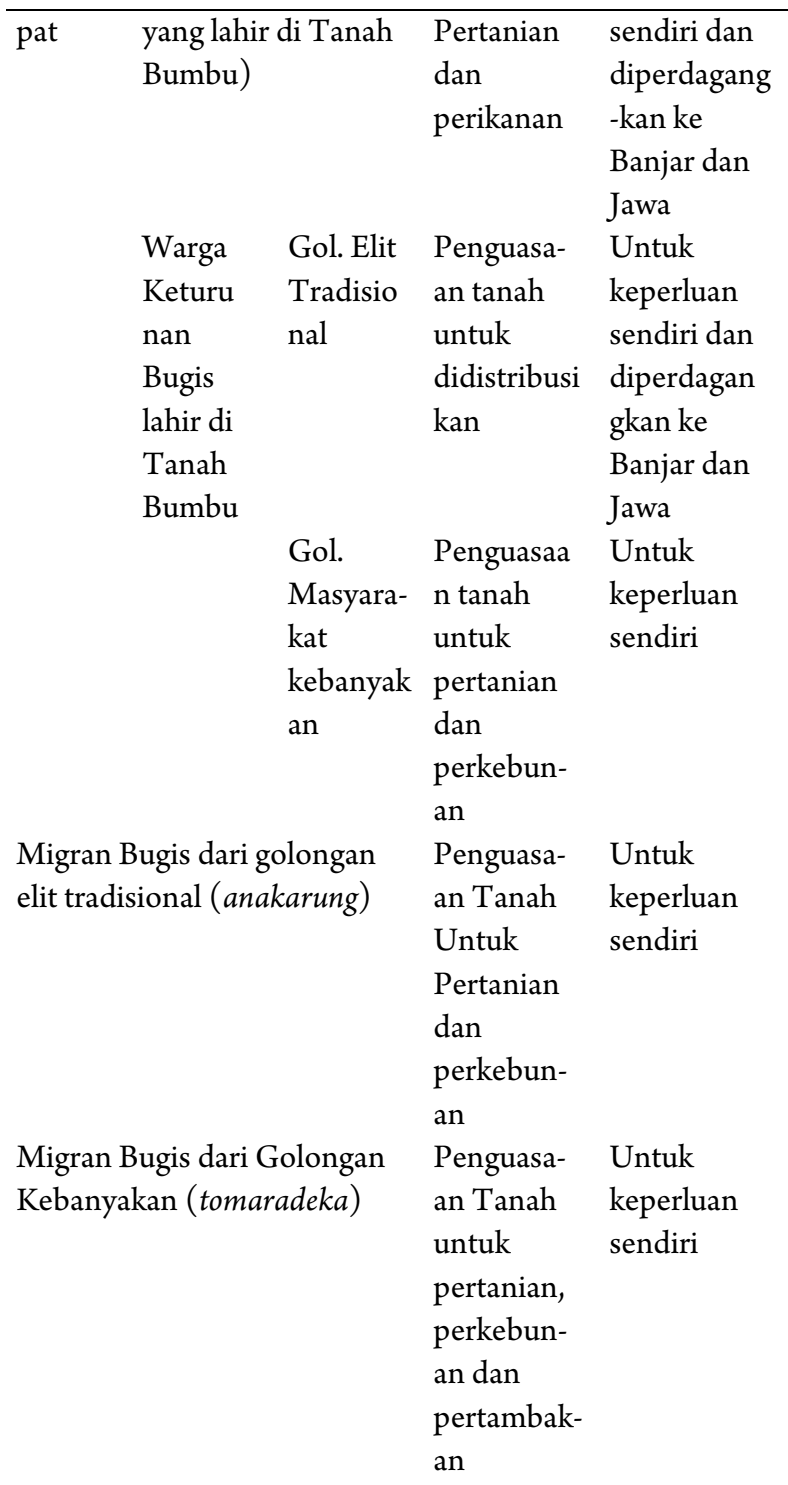

Sumber: diadaptasi Lenggono, 2011: 93.

Berdasar kemunculannya, para ponggawa di Tanah Bumbu pada 1940-an dapat dibagi ke dalam tiga kelompok: pertama, kelompok ponggawa/ juragan perintis (menjadi ponggawa sebelum 1900-an); kedua, ponggawa/ juragan pengikut (1920-1930); dan ketiga, ponggawal juragan penerus (1930-1940). Golongan ponggawa/juragan penerus menjadi ponggawal juragan karena faktor keturunan atau pewarisan usaha. Para ponggawa yang mampu bertahan dan berhasil mengembangan usahahanya adalah mereka yang tidak hanya berhasil melakukan hegemoni secara ekonomi dan sosio-kultural, namun juga adaptif dalam melihat perubahan (Wawancara dengan Abdul Kadir Wellang, 2012). 
Terkait dengan stratifikasi sosial masyarakat Bugis di Tanah Bumbu secara garis besar hanya terdiri atas dua lapisan, yaitu Ajjoareng (pemimpin) dan Joa' (pengikut). Kedua lapisan tersebut dipisahkan oleh statusnya. Pemisahan status sendiri, berdasar pada penguasaan kapital (modal) dan alat produksi. Khusus Ajjoareng (pemimpin) sendiri terbagi lagi dalam kelompok ponggawa/ juragan besar, ponggawa/ juragan menengah dan ponggawa/ juragan kecil (Pelras, 2000: 400405). ${ }^{3}$

Pada lapisan joa', terdapat tiga status, yaitu sawi (anak buah) orang yang bekerja sendiri dengan kapal kecil, sawi (anak buah) yang dipekerjakan ponggawa/ juragan, dan sawi (anak buah) penangkap ikan yang dijual dalam jumlah besar. Meskipun demikian, pelapisan tersebut tidak selalu terimple-mentasi secara ketat, karena terdapat pula seorang penangkap ikan (nelayan) bekerja sendiri, yang "bebas" atau tidak terikat pada seorang ponggawa/ juragan yang tidak bisa diklasifikasikan sebagai joa' (pengikut) karena ia seorang pekerja mandiri. Adapun pembagian lapisan masyarakat dan status pada masyarakat Bugis Tanah Bumbu 1920-1940, terdapat dalam Tabel 4.

Bagi orang Bugis, usaha memperkaya diri sebagai suatu kewajiban, sepanjang dilakukan secara jujur dan halal (sappa' dalle' hallala'). Mereka bahkan mempertaruhkan siri' (rasa malu)-nya ketika meran-tau dan merasa "malu" bila tidak bisa pulang untuk memperlihatkan bukti keberhasilannya. Menjadi orang yang berharta memungkinkan mereka mampu membantu sesama yang kurang beruntung, setidaknya juga menutup kemungkinan terjerumus menjadi ata (budak) dan kehilangan siri'(rasa malu)-nya (Pelras, 2000: 405).

Tabel 4. Pembagian Lapisan Masyarakat, Golongan dan Status pada Masyarakat Bugis Tanah-Bumbu, 1920-1940-an

\begin{tabular}{ccc}
\hline Lapisan & \multicolumn{1}{c}{ Golongan } & \multicolumn{1}{c}{ Status } \\
\hline Ajjoareng & $\begin{array}{c}\text { 1. Ponggawa/juragan } \\
\text { Besar }\end{array}$ & $\begin{array}{l}\text { Ponggawa/ } \\
\text { juragan }\end{array}$ \\
& $\begin{array}{c}\text { 2. Ponggawa/juragan } \\
\text { menengah dan }\end{array}$ & \\
& &
\end{tabular}

\begin{tabular}{lll}
\hline Joa/ pengikut & kecil & \\
klien & 1. Penangkap ikan & Nelayan kecil \\
& dengan kapal & Penyambang \\
& kecil tanpa anak & Penjaga \\
& buah atau sawi. & Empang/tam- \\
2. Kalangan anak & baruh) \\
& buah/sawi & \\
& penangkap & \\
& ikanyang dipekerjak & \\
& an \\
& ponggawa. & \\
3. Sawi /anak buah & \\
& atau penangkap & \\
& ikan untuk & \\
& perikanan yang \\
& dijual dalam & \\
& jumlah besar.
\end{tabular}

Sumber: Nuralang, 2007: 12.

\section{Bahuma (bertani) dan Membuat Kopra}

Migran Bugis tidak hanya berkecimpung dalam bidang perikanan, tetapi terdapat juga yang berprofesi sebagai petani di Tanah Bumbu. Menurut Pelras dalam Lenggono, para perantau Bugis bukan sekedar petani tradisional, tetapi adalah pengusaha berorientasi ekonomi. Berbeda dari orang Jawa yang memiliki konsep keberhasilan yang diukur berdasar kemampuan untuk semakin memperluas sawah atau kebun guna mengintensifkan dan meningkatkan produksi pertanian, para petani Bugis justru memiliki pemikiran berbeda. Menurut Tanaka, jika petani Bugis memperoleh uang yang besar, mereka lebih memilih menginvestasikan kembali uang itu dalam bidang lain, seperti transportasi, perniagaan atau menyewakan lahan kepada petani dari suku Jawa atau orang Bugis yang baru tiba dan selanjutnya mereka akan mencari tempat-tempat yang lebih menguntungkan. Bagi migran Bugis, ikatan mereka dengan tanah yang dikuasainya tidak lebih dari "ikatan instrumenttal”, jika mereka menganggap tanah-tanah yang dikuasainya tidak lagi menguntungkan, mereka akan segera menyewakan atau dijualnya dengan harga layak (Lenggono, 2011: 171). Tidak terdapat data jumlah petani Bugis yang ada di wilayah Tanah Bumbu. Akan tetapi, dari data Volkstelling 1930, terdapat data-data tentang 
persentase jumlah petani di wilayah tersebut dalam Tabel 5.

Tabel 5. Persentase Petani dari Setiap 100 Pekerja di Residensi Borneo bagian Selatan dan Timur

\begin{tabular}{llccc}
\hline No & \multicolumn{1}{c}{ Daerah } & $\begin{array}{c}\text { Laki } \\
\text { Laki }\end{array}$ & Perempuan & Prosentase \\
\hline 1. & Koealakapoeas & 88,35 & 82,03 & 83,07 \\
2. & Bandjarmasin & 55,04 & 44,87 & 52,28 \\
3. & Zuid Oostkust & 74,07 & 55,23 & 68,57 \\
& van Borneo & & & \\
4. & Hoeloesoengai & 81,40 & 82,08 & 81,59 \\
5. & Samarinda & 60,26 & 38,89 & 52,49 \\
6. & Bulungan & 20,27 & 7,45 & 14,74 \\
& Total & 70,42 & 59,24 & 67,11 \\
\hline
\end{tabular}

Sumber: Departement van Landbouw, Nijverheid en Handel, 1930: 47.

Berdasar Tabel 5 diperoleh informasi mengenai jumlah petani di wilayah Residensi Borneo (Kalimantan) bagian Selatan dan Timur adalah sekitar $68,57 \%$ dari sekitar 100\% pekerja di wilayah ini. Rinciannya persentase petani laki laki adalah $74,07 \%$. Sementara itu, petani perempuan adalah $55,23 \%$ dari jumlah setiap 100 pekerja di wilayah ini. Dengan demikian berarti jumlah petani di sekitar wilayah Residensi Borneo (Kalimantan) bagian Selatan dan Timur cukup besar dibandingkan dengan bidang lainnya seperti perikanan dan perdagangan.

Walaupun memiliki tanah yang luas, sejumlah migran Bugis diketahui enggan menjual tanah miliknya yang dianggap memiliki nilai historis tertentu. Selanjutnya mereka berusaha mencari tanah-tanah yang lebih "menguntungkan" dan sering kali mengikuti jejak keberhasilan orang lain (meskipun berbeda etnis). Hal ini bisa dilihat dari kemampuan adaptasi para migran Bugis yang mampu mengadopsi kegiatan pertanian padi dengan sistem handil atau bahuma yang dikembangkan migran Banjar ataupun sistem perladangan berpindah yang dipraktekkan penduduk asli setempat (Dayak) (Levang, 2010: 165).

Para migran di wilayah Tanah Bumbu juga membuka perkebunan kelapa untuk kopra yang memiliki harga menarik di pasaran atau pun perikanan tangkap. Selain itu, mereka juga melakukan tukar-menukar hasil perikanan tangkap dengan barang kebutuhan pokok yang mereka butuhkan dengan para pedagang perantara dari Pangkajene. Para pemimpin komunitas Bugis di Kampoeng Baroe (kampung tertua di kawasan Pagatan, Tanah Bumbu) tampaknya tidak terlalu banyak mendapatkan keuntungan dari kegiatan perdagangan hasil produksi pertanian dan perikanan tersebut. Oleh karena itu, tidak sedikit dari para migran Bugis tersebut yang kemudian terlibat dalam kegiatan ilegal dengan bergabung menjadi perompak di perairan pantai timur dan selatan Borneo (Kalimantan). ${ }^{4}$

Menjelang 1940-an, di dalam kawasan Tanah Bumbu telah berkembang perkampungan-perkampungan baru, seperti Pakkaja yang dibangun oleh migran Bugis yang berasal dari Sulawesi Selatan. Dari penelitian Balai Arkeologi Banjarmasin, menunjukkan banyak lokasi-lokasi pertanian dan perkebunan di kawasan tersebut yang dulunya merupakan area jelajah pertanian dan perkebunan dari penduduk Tanah Bumbu. Pada masa tersebut warga di perkampungan tersebut diketahui telah melakukan hubungan perdagangan dengan melakukan transaksi jual beli kopra, melalui pedagang-pedagang di Banjarmasin (Nuralang, 2007: 17). Namun sulitnya medan yang harus ditempuh dan minimnya akses yang bisa digunakan nelayannelayan di dalam kawasan Tanah Bumbu, serta dampak krisis ekonomi 1930 telah memaksa sebagian dari mereka masuk dalam kegiatan jaringan penyelundupan kopra antarpulau. Banyak pemilik perahu Bugis tidak hanya melakukan kegiatan di sektor perikanan tangkap, namun juga berperan serta dalam kegiatan penyelundupan berbagai bahan makanan dan kopra hingga ke wilayah Tawau, Malaysia (Wawancara dengan Usman Lundrung, 2012).

\section{Mengembangkan Usaha Perahu Rakyat dalam Bidang Transportasi Laut}

Seiring dengan keberadaan orang-orang Bugis bermukim di pesisir timur dan selatan Borneo (Kalimantan) pada 1900-an, turut berkembang 
pula aspek pelayaran dan perdagangan. Selain itu, muncul beberapa pelabuhan laut yang melayani perdagangan antar pulau, seperti pelabuhan Pagatan di Keresidenan bagian Selatan dan Timur yang dikembangkan orangorang Bugis. Berawal dari Kampoeng Pagattang yang dibuka oleh Puanna Dekke pada 1830, berkembang menjadi bandar kecil yang strategis berbatasan dengan Laut Jawa dan berada di daerah aliran Sungai Kusan (Muller, 1857: 301).

Oleh karena itu, keberadaan pelabuhan kecil Pagatan dapat digolongkan dalam daerah expansion of Bugis trade. Kemudian pada 1900 berkembang pelabuhan Batulicin dan Kotabaru. Pelabuhan ini berkembang karena interaksi perdagangan, baik penduduk asli, migran dari Sulawesi Selatan maupun peran pemerintah kolonial Belanda yang melakukan pengangkutan batubara di wilayah Pelabuhan Kotabaru (Pulau Laut). Sejak pertengahan abad ke-19 hingga awal abad ke-20, pelabuhan Pagatan dan Batulicin menjadi pelabuhan perahu rakyat alternatif di samping pelabuhan utama Kotabaru dan pelabuhan besar Banjarmasin di kawasan Keresidenan Borneo (Kalimantan) bagian Selatan dan Timur (Abidin, 1983: 61).

Mengenai jalur perdagangan awal di wilayah Tanah Bumbu dapat ditelusuri kembali dari catatan Van der Ven. Pada 1846 terdapat dua kapal bermuatan rotan dan lilin berlayar dari Pagatan ke Singapura. Dalam hal ini, peranan penting jalur pelayaran perahu rakyat di daerah Pagatan sudah muncul sejak abad ke-19. Bahkan, terbentuk pelayaran antarpulau atau interinsuler yakni Pagatan-Makassar, Pagatan-Jawa dan Pagatan-Singapura. Demikian halnya diungkapkan Poelinggomang, perdagangan antara Makasar-Maluku dan Timor serta Makassar dengan kepulauan lainnya (Bali, Lombok, Sumbawa dan Borneo) berkembang pesat antara tahun 1830-1846 (Poelinggomang, 2002: 144).

Kemudian dari catatan van der Stok tahun 1863, dilaporkan bahwa salah satu pemasukan impor di Pulau Selayar adalah barang dari Pagatan yakni sejumlah komoditas dengan total biayanya $\mathrm{f} 405$. Sayangnya van der Stok tidak merinci barang-barang yang berasal dari Pagatan tersebut. Hanya dalam daftar barang impor di Pulau Selayar terdapat dua komoditas yang dihasilkan di wilayah Pagatan yakni rotan dan gambir. Adapun jumlah perahu dari Pagatan terdapat dua buah dengan biaya $\mathrm{f} 9,5$ per satuan komoditasnya (van der Stok, 1931). Jalur pelayaran dan perdagangan interinsuler dari dan ke wilayah Pagatan tersebut bisa dikategorikan sebagai jalur sepi karena sedikitnya kapal yang melewati jalur tersebut. Walaupun demikian, keberadaan pelayaran ini sudah menggambarkan bahwa hubungan antara migran Bugis dengan daerah asal di Sulawesi Selatan sudah terjaga dan berlangsung secara kontinu sejak abad ke-19. Selain data tersebut, hanyalah data umum yang bisa didapatkan dari data-data statistik tentang perdagangan di Borneo (Kalimantan) bagian selatan dan timur.

Kelangkaan catatan statistik tentang volume perdagangan di wilayah Tanah Bumbu yang dilakukan oleh orang Bugis ini, kemungkinan karena perdagangan umumnya dilakukan oleh perahu layar secara tradisional. Perahu layar yang dipergunakan dalam perdagangan antarpulau pada 1900-an adalah perahu pinisi, pelari maupun sekonyer. Jenis perahu inilah yang dipergunakan atau berfungsi sebagai perahu layar yang mengarungi laut atau samudera biasanya membawa lepa lepa yang berfungsi sebagai sekoci pada kapal laut yang besar. Biasanya perahu atau lepa-lepa ini diikat di buritan perahu layar yang mengarungi laut atau samudera. Ini dipakai sebagai alat transportasi dari perahu layar tersebut ke darat atau pantai ketika perahu tersebut berlabuh atau singgah pada suatu tempat di wilayah Nusantara (Syarifuddin, 1992: 30). Selain itu, kemungkinan karena jalur pelayaran dan perdagangan yang tidak ramai di wilayah Tanah Bumbu (Pelabuhan kecil Pagatan dan Batulicin) sehingga sangat jarang sekali terdapat catatan statistik tentang pelayaran dan perdagangan di wilayah ini. ${ }^{5}$

Dalam perkembangannya, dengan munculnya armada KPM yang dimotori pemerintah Hindia Belanda, peranan perahu layar seperti di pelabuhan Pagatan, Kotabaru dan 
Batulicin pun berubah fungsi. Menurut Endang Susilowati, kapal layar berubah menjadi alat transportasi pembantu atau feeder vessels. Hal ini tampak dengan makin menurunnya jumlah dan kapasitas perahu yang singgah di pelabuhanpelabuhan utama di Indonesia sampai dengan pertengahan tahun 1920-an, dengan perkecualian pelabuhan Makassar (Susilowati, 2004: 15-160). Dalam hal ini, keberadaan armada perahu KPM di beberapa kasus di pelabuhan besar memang menggantikan posisi perahu rakyat. Namun tidak demikian halnya dengan pelayaran perahu di daerah Pagatan. Keberadaan perahu rakyat justru menjadi penyuplai komoditas perdagangan dari para pedagang pribumi. Kemudian perahu rakyat ini juga melakukan pelayaran dan perdagangan ke rute yang dilalui oleh kapal KPM milik pemerintah Belanda (Susilowati, 2004: 6).

Dinamika pelayaran perahu terjadi pada 1930 secara global. Hal ini dilatarbelakangi krisis ekonomi atau yang lebih dikenal dengan malaise. Pada 1930 merupakan puncak terjadinya krisis ekonomi yang bersekala internasional. Tentu saja, bagi wilayah Hindia Belanda sangat terpukul dengan adanya krisis tersebut, karena banyak produksi yang berorientasi ekspor sangat rentan terhadap siklus perdagangan.

Krisis ini telah membawa dampak negatif terhadap aktivitas pelayaran dan perdagangan di Hindia Belanda, terutama bagi pelayaran kapal uap secara keseluruhan, termasuk KPM. KPM sebagai pemegang monopoli pelayaran antarpulau mengalami banyak kesulitan sehubungan dengan krisis tersebut. Jatuhnya harga berbagai komoditas telah menyebabkan para pedagang tidak bisa membayar premi untuk pelayanan KPM yang tinggi. Pedagang menginginkan kapal laut yang lebih murah biayanya dibandingkan kapal KPM. Keinginan para pedagang itu tentunya merupakan kabar gembira bagi armada kapal kecil dan armada perahu.

Pada saat itu telah dikembangkan kapal kayu bermesin diesel yang biaya operasionalnya jauh lebih ekonomis dibandingkan kapal uap, sehingga tarifnya pun lebih murah. Di samping kapal kayu, untuk memenuhi kebutuhan akan sarana transportasi laut yang murah, armada perahu layar tampil sebagai "penyelamat" karena kapal uap sedang collapse. Tidak hanya para pedagang pribumi saja yang kemudian berpindah untuk mengangkut barang dagangan mereka, tetapi juga banyak firma dagang Cina dan Eropa yang memanfaatkan sarana transportasi murah tersebut (Susilowati, 2004: 150-151). Sebagai gambaran hubungan antara pedagang pribumi dengan armada dagang KPM dapat dilihat pada Gambar 2.

Dari periode 1929 hingga 1931 yang berlanjut hingga 1942, rata-rata muatan perahu di berbagai pelabuhan di Hindia Belanda mengalami kenaikan, sedangkan muatan kapal uap menurun. Pada tahun-tahun tersebut, pelayaran kapal uap dapat dikatakan mengalami kelumpuhan karena biaya operasi yang tinggi tidak mungkin dapat tertutup dalam kondisi pasar yang sangat lesu. Perahu yang berteknologi sederhana justru tetap dapat survive dan bahkan menjadi andalan pedagang dalam perdagangan antarpulau. Dalam masa depresi ekonomi, jalurjalur pelayaran utama kembali diramaikan oleh kiprah perahu layar (Susilowati, 2004: 150-151).

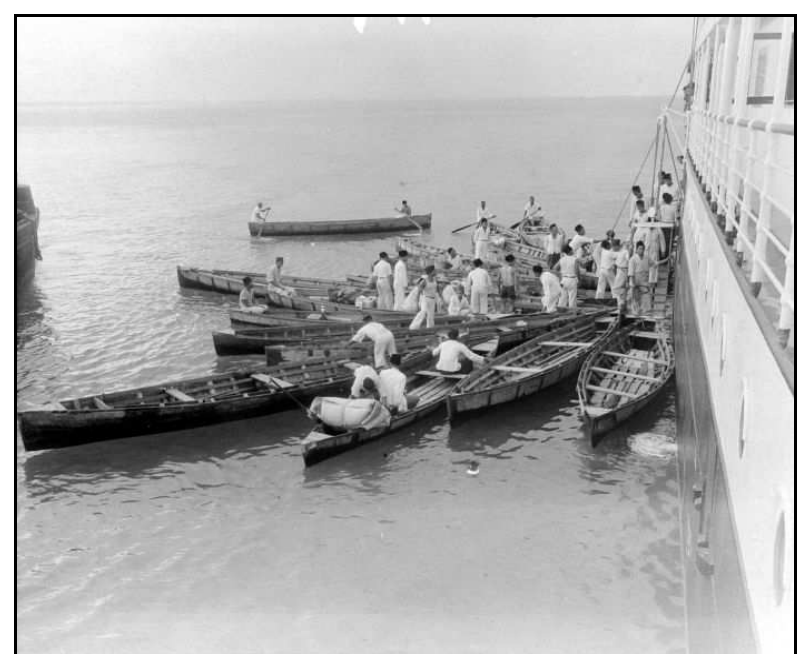

Gambar 2. Perahu Pedagang Bugis dan Kapal KPM di Kotabaru, 1940

Sumber: http://www.kitlv.nl.eo, 2012.

Pada masa krisis tersebut pelayaran perahu telah berekspansi keluar peranannya sebagai vedeer vessel dan melayani jaringan antarpulau secara intensif karena permintaan 
pasar. Bahkan tidak menutup kemungkinan juga telah terjadi diversifikasi dalam pelayaran dan perdagangan oleh armada perahu dalam kurun waktu krisis ekonomi tersebut. Misalnya, pada 1931 di Bima terjadi kegagalan panen bawang putih, namun pada musim angin timur pangkalan perahu di Bima tetap dipadati perahuperahu Bugis. Kecuali itu, para pedagang di pantai timur Borneo (Kalimantan) mulai mendatangkan bawang putih langsung dari Bima tanpa melalui Makassar (Susilowati, 2004: 150).

Sebagai pelabuhan kecil alternatif, pelabuhan Pagatan memang tidak terkena dampak malaise secara langsung. Akan tetapi, krisis ini malah mendorong makin ramainya pelayaran perahu rakyat ke Pagatan yang menjadi alternatif perdagangan yang melayani perdagangan ke daerah Borneo (Kalimantan) bagian selatan dan timur. Satu hal yang menjadi perkembangan penting, posisinya yang strategis dalam jaringan perdagangan Borneo-CelebesJawa, selain pelabuhan Banjarmasin. Apalagi menurunnya volume pelayaran kapal uap, menjadikan Pagatan sebagai salah satu pelabuhan kecil alternatif di dekade 1930 sampai 1942. Karena posisinya yang strategis, dalam kurun waktu 1930 sampai 1942 tersebut, daerah Pagatan juga menjadi salah satu rute pelayaran Roepelin dengan Surabaya sebagai pangkalannya. Rute ke Borneo (Kalimantan) ini melayani pelabuhan di Borneo (Kalimantan) bagian barat, timur dan selatan, seperti Banjarmasin, Kotabaru, Pagatan, Balikpapan, Samarinda dan Pontianak. Untuk rute pelayaran ini, muatan yang diangkut berbagai macam barang impor, beras, gula, botol kosong, dan besi tua. Pelayaran kembali ke Surabaya mengangkut kayu, kopra dan kelapa (Susilowati, 2004).

\section{SIMPULAN}

Dari pembahasan dapat disimpulkan bahwa terdapat tiga faktor yang mendorong dan sekaligus daya tarik migrasi dan terbentuknya jaringan ekonomi Suku Bugis di wilayah Tanah Bumbu. Faktor pertama adalah faktor alam, berhubungan dengan potensi sumber daya alam di pesisir Tanah Bumbu yang memungkinkan dikelola. Kemudian faktor politik, berhubungan dengan kondisi politik di Sulawesi Selatan yang tidak memungkinkan lagi untuk menunjang penghidupan. Selanjutnya adalah faktor ekonomi, berhubungan dengan upaya migran Bugis di Tanah Bumbu untuk meningkatkan taraf kehidupannya di tanah rantau.

Ketiga hal ini mengindikasikan begitu kuatnya keinginan bertahan hidup dan motif ekonomi dalam setiap mobilitas yang dilakukan orang Bugis menjadi pendorong yang luar biasa untuk selalu mencari peluang ekonomi dan penghidupan yang lebih baik di berbagai tempat yang mereka datangi. Hal itu tampaknya menjadi ciri khas yang melekat dalam diri orang Bugis.

Wilayah Tanah Bumbu yang secara administratif terletak di Afdeeling Pasir en de Tanah Boemboe, Residentie Borneo's Zuid en Oosterafdeeling (Karesidenan Borneo Bagian Selatan dan Timur) merupakan tempat migrasi terbesar orang Bugis, jika dibandingkan berbagai wilayah lain di Indonesia. Di wilayah tersebut orang Bugis beradaptasi dan berusaha membangun penghidupan di tanah yang baru. Secara bertahap mereka membentuk suatu jaringan ekonomi orang Bugis. Dalam kurun waktu 1930, keberadaan ponggawa Bugis turut memberikan andil terhadap perkembangan ekonomi di Tanah Bumbu di tengah depresi ekonomi. Usaha perikanan ini dibangun oleh orang Bugis yang berasal dari strata sosial tomaradeka (orang merdeka) dan anakarung (bangsawan/elit tradisional). Karena faktor depresi ekonomi 1930, orang Bugis di Pagatan juga mengembangkan sistem pertanian bahuma (bertani) dan membuat kopra menjadi bagian dari strategi adaptasi ekonomi. Orang Bugis juga mengembangkan usaha perahu rakyat dalam bidang transportasi laut. Armada perahu rakyat yang dipergunakan dalam perdagangan antarpulau pada 1930-an adalah perahu pinisi, pelari, dan sekonyer. Pada masa malaise usaha yang terakhir ini utamanya mampu bertahan dan berkembang, bahkan dapat bersinergi dengan pemerintah Hindia Belanda. 


\section{CATATAN}

${ }^{1}$ Pembagian wilayah Borneo/Kalimantan berdasarkan "Besluit van den Minister van Staat, Gouverneur Generaal van Nederlandsch-Indie”, 27 Agustus 1849 No. 8, Staatsblad van Nederlandisch Indie voor het Jaar 1849. Batavia: Ter Lands Drukkerij, hlm.1-2; "De Minister van Staat, Gouverneur Generaal van Nederlandsc Indie”, dalam L.J.A. Tollens (1856). Verzameling van Wetten, Besluiten, Bepalingen, Kennisgaven, enz, over de Jaren 18081856, Tweede Deel. Batavia: Lange \& Co., hlm. 160; "Het Eiland Borneo en Zijne Bewoners", dalam J. B. J. van Dooren (1860). Bijragen tot de Kennis van Verschillende Overzeesche Landen, Volken, enz, Eesrste Deel. Amsterdam: J.D. Sybrandi, hlm. 241.

${ }^{2}$ Departement van Landbouw, Nijverheid en Handel (1930). Volkstelling (Population Census), Definitieve Uitkomsten van de Volkstelling 1930. Batavia: Departement van Landbouw, Nijverheid en Handel, hlm. 28, 47-8; Lihat juga Muhammad Idrus Abustam (1983). "Gerak Penduduk, Pembangunan dan Perubahan Sosial Kasus Tiga Komunitas Padi Sawah di Sulawesi Selatan”. Tesis pada Institut Pertanian Bogor, hlm. 260: Lihat juga Widjojo Nitisastro (1970). Population Trends in Indonesia. Ithaca \& London: Cornell University Press, hlm. 88-91.

${ }^{3}$ Mengenai hubungan Ajjoareng dan Joa, lihat Christian Pelras (2000). "Patron-Client Ties Among the Bugis and Makassarese of South Sulawesi", Authority and Enterprise Among the Peoples of South Sulawesi. Leiden: KITLV, hlm. 400-405.

${ }^{4}$ Mengenai perompakan dan perdagangan gelap di Borneo (Kalimantan) sebenarnya sudah berlangsung lama sejak pertengahan abad ke-19. Sebagaimana dilaporkan dalam laporan Politik Hindia Belanda terdapat perompakan Aji Bedu dan Daeng Manggading di wilayah Tanjung Selatan dan Batulicin pada tahun 1845-an. Lihat ANRI (1973). Ikhtisar Keadaan Politik Hindia Belanda Tahun 1839-1848. Djakarta: Arsip Nasional Republik Indonesia, hlm. xci.

${ }^{5}$ Misalnya dalam kumpulan data statistik Jeroen Touwen (2000). Shipping and Trade in The Java Sea Region 18701940: A Collection of Statistics on the Major Java Sea Region hanya membahas tentang data statistik pelayaran dan perdagangan di wilayah Banjarmasin tanpa memuat data data tentang pelabuhan pelabuhan kecil di wilayah sekitarnya.

\section{REFERENSI}

Abidin, Andi Zaenal (1983). Persepsi Orang Bugis, Makasar Tentang Hukum, Negara dan Dunia luar. Bandung: Alumni.

Abustam, Muhammad Idrus (1983). "Gerak Penduduk, Pembangunan dan Perubahan Sosial Kasus Tiga Komunitas Padi Sawah di
Sulawesi Selatan”. Tesis pada Institut Pertanian Bogor.

ANRI (1973). Ikhtisar Keadaan Politik Hindia Belanda Tahun 1839-1848. Djakarta: Arsip Nasional Republik Indonesia.

ANRI (1849). "Besluit van den Minister van Staat, Gouverneur-Generaal van Nederlandsch-Indie", tanggal 27 Agustus 1849 No. 8, Staatsblad van Nederlandisch Indie Voor Het Jaar 1849. Batavia: Ter Lands Drukkerij.

BPS Kabupaten Tanah Bumbu (2009). Tanah Bumbu dalam Angka 2009. Batulicin: BPS Tanah Bumbu.

Bleckmann, G. M. (1953). "Iets over het Noodzake-lijke en Voorkelige Eener Negerlandshe Vestiging op de Ooskust van Borneo", dalam Jacob swart, Verhandelingen en Berigten Betrekkelijk het Zeewegen, Zeevaartkunde, de Hydrographie, de Kolonien. Amsterdam: G. Hulst van Keulen.

Burger, D. H. (1960). Sejarah Ekonomi Sosiologis Indonesia. Jakarta: Pradnja Paramita.

De Wit, Augusta (1940). Natuur in Zuid en Oost Borneo, Fauna, Flora en Natuurbescherming in de Zuider en Oosterafdeling van Borneo. door de Ned. Indie Vereeniging tot Natuur-bescherming, 1926-1940.

Departement van Landbouw, Nijverheid en Handel (1930). Nijverheid en Handel: Volkstelling (Population Census), Definitieve Uitkomsten van de Volkstelling 1930. Batavia: Departement van Landbouw, Nijverheid en Handel.

Gooszen, A. J. (1999). A Demographic History of the Indonesian Archipelago, 1880-1942. Nether-lands: KITLV Press.

Hugo, Greeme J. et. al. (1987). The Demographic Dimension in Indonesian Development. Singapore: Oxford University Press.

Hollander, J. J. (1864). Borneo's Zuider en Ooster Afdeling. Handleiding bij de Beoefening der Land en Volkenkunde van Nederlansch Oost Indie, Koninklijke Militaire Akademie. 
Ideham, M. Suriansyah et. al. (ed.) (2003). Sejarah Banjar. Banjarmasin: Pemerintah Provinsi Kalimantan Selatan.

Kartodirdjo, Sartono (1999). Pengantar Sejarah Indo-nesia Baru: Sejarah Pergerakan Nasional dari Kolonialisme Sampai Nasionalisme, Jilid 2. Jakarta: Gramedia.

Koroh, Alex A. (2009). Lintasan Sejarah Pemerintahan Daerah di Kalimantan Selatan 1901-1957. Banjarbaru: Scripta Cendekia.

Koninklijk Instituut voor Taal, Land en Volkenkunde (KITLV) (1940). Armada KPM di Pelabuhan Stagen (Kotabaru). Diperoleh dari http:// www.kitlv.nl.eo.

Lenggono, P. Setia (2011). "Ponggawa dan Patronase Pertambakan di Delta Mahakam, Teori Pembentukan Ekonomi Lokal”. Disertasi pada Sekolah Pascasarjana Institut Pertanian Bogor.

Levang, Patrice (2010). La Terre de en Face: La Transmigration en Indonesia (Ayo ke Tanah Sabrang: Transmigrasi di Indonesia), terjemahan Sri Ambar Wahyuni Prayoga. Jakarta: Kepustakaan Populer Gramedia.

Linneton, Jacqueline (1973), "Passompe' Ugi': Bugis Migrants and Wanderers”, Archipel, Volume 10.

Muller, Solomon (1857). "Reis duur een gedeelte der Sultans en zoogenaamde Lawut landen, ten oosten en zuidoosten van de hoofdlaats Bandjermasin” dalam Reizen en Onderzoekingen in den Indischen Archipel, gedaan op las der Nederladsche Indische Regering, Tussen de Jaren 1828 en 1836, Eerste Deel. Amsterdam:Frederik Muller.

Naim, Mochtar (1979). Merantau: Pola Migrasi Suku Minangkabau. Yogyakarta: Gadjah Mada University Press.

Nitisastro, Widjojo (1970). Population Trends in Indonesia. Ithaca \& London: Cornell University Press.

Nuralang, Andi (2007). "Jejak Komunitas Bugis Makassar, Suatu Indikasi Adaptasi Lingkungan: Tinjauan Sejarah dan Arkeologi”. Balai Arkeologi Banjarmasin.
Pelras, Christian (2000). "Patron-Client Ties Among the Bugis and Makassarese of South Sulawesi”. In Authority and Enterprise Among the Peoples of South Sulawesi. Leiden: KITLV.

Poelinggomang, Edward L. (2002). Makassar Abad XIX: Studi Tentang Kebijakan Perdagangan Maritim. Jakarta: Kepustakaan Populer Gramedia.

Susilowati, Endang (2004). Pasang Surut Pelayaran Perahu Rakyat di Pelabuhan Banjarmasin, Tahun 1880-1990. Disertasi pada Universitas Indonesia, Jakarta.

Schwaner, Carl Anton Ludwig Maria (1853). Historische, Geograpische en Statistieke Aantee-keningen Betreffende Tanah Boemboe. Tidjschrift Voor Indische Taal Land en Volkenkunde, Batavia: Lange \& Co.

Stanford's Geographical Establishment (1919). Diperoleh dari https://exhibits. stanford.edu.

Syarifuddin (1992). Perahu Bugis Pagatan. Banjarbaru: Museum Negeri Lambung Mangkurat, Provinsi Kalimantan Selatan.

Touwen, Jeroen (2000). Shipping and Trade in the Java Sea Region 1870-1940: A Collection of Statistics on the Major Java Sea Region. Semarang: Diponegoro University Press.

Stok, N. V. van der (1866). "Het Eiland Saleier". In Tijdscrift voor Indische Taal Land en Volkenkunde. Uitgeven Door Het Bataviaasch Genootschap van Kunsten en Waten-schappen. Deel XV. Batavia: sHage \& M. Nijhoff.

Veth, Pieter Johannes (1869). Aardrijkskundig en statistisch woordenboek van Nederlandsch Indie. Amsterdam: Van Kampen.

\section{WAWANCARA}

Andi Tajuddin, 20 Maret 2012.

Abdul Kadir WellangTanah Bumbu, 3 Maret 2012.

Bustani Azhar, 24 Maret 2012.

Usman Lundrung, 23 Maret 2012. 
M. Koding (Zainuddin), Tanah Bumbu, 20 Maret 2012.

M. Kasran Hamid, Tanah Bumbu, 20 Maret 2012. 